\title{
Baleias e ecologistas na Paraíba: uma história do fortalecimento do movimento ambientalista e o debate sobre a crise da economia baleeira (1970-1980)
}

\author{
Francisco Henrique Duarte Filho* \\ José Otávio Aguiar ${ }^{* *}$
}

\section{RESUMO}

A atividade baleeira perdurou por quase quatro séculos no Brasil (1603-1987), tendo sido encerrada no país depois de 384 anos de vigência. O governo José Sarney (1985-1990), pressionado por organismos de proteção ambiental e pela opiniáo pública, proibiu definitivamente a caça por meio da Lei Federal no 7.643, em dezembro de 1987. A lei motivou questionamentos e debates em nível local e nacional em razão de eventuais prejuízos que o fim da atividade baleeira traria para a economia do município de Lucena e para o estado da Paraíba. Este artigo deseja lançar interrogaçóes sobre a crise da atividade baleeira no Brasil, analisando os debates que ocorreram entre biólogos, políticos, ambientalistas e trabalhadores da indústria baleeira localizada no município de Lucena. Para tanto, recorrerá tanto à bibliografia disponível sobre o tema quanto aos jornais do período, principalmente os jornais paraibanos publicados na década de 1980.

Palavras-chave: baleias; história ambiental; desenvolvimento; jornais.

\section{ABSTRACT}

Whaling lasted for almost four centuries in Brazil (1603-1987). Pressed by environmental protection agencies and the public opinion, the José Sarney Administration (1985-1990) permanently banned whale hunting in December 1987, through the Federal Law 7,643. The law prompted a local and national debate on any losses the end of whaling would bring to the economy of the city of Lucena and the state of Paraíba. This article discusses the crisis of whaling in Brazil by analyzing the debates that occurred among biologists, politicians, environmentalists and the whaling industry workers in the municipality of Lucena. Both

Artigo recebido em 3 de março de 2013 e aprovado em 22 de fevereiro de 2014.

DOI - http://dx.doi.org/10.1590/2237-101X015028004

* Doutor em recursos naturais pela Universidade Federal de Campina Grande (UFCG), professor do Instituto Federal de Pernambuco (IFPE). Belo Jardim, PE, Brasil. E-mail: henrique.bj@ibest.com.br.

** Doutor em história e culturas políticas pela Universidade Federal de Minas Gerais (UFMG), professor da Universidade Federal de Campina Grande (UFCG). Campina Grande, PB, Brasil. E-mail: 
the available academic literature on the subject and newspapers of the 1980s were used, especially Paraíba's publications of the period.

Keywords: whales; environmental history; development; newspapers.

\section{A caça à baleia no Brasil, o movimento ambientalista e os debates sobre o fim da atividade no litoral da Paraíba (1980-1990)}

Na década de 1980, em vários estados brasileiros, ocorreram mobilizaçóes e abaixo-assinados para que o governo federal tomasse uma decisão sobre a questão da atividade baleeira no país. Movimentos de mobilização contra a "pesca da baleia” nas escolas, principalmente envolvendo crianças, foram noticiados pela imprensa. ${ }^{1}$ Em algumas escolas públicas, como ocorreu no estado de São Paulo, as lideranças organizaram milhares de pedidos, cartas assinadas por alunos que foram endereçadas ao presidente da República apelando para que o mesmo interviesse na luta pelo fim da matança das baleias. Igualmente, artistas do país já consagrados, como Roberto Carlos e Erasmo Carlos, compuseram música ${ }^{2}$ no ano de 1981 abordando a questão da caça predatória imposta às baleias em mares e oceanos. A canção, claramente de apelo à causa preservacionista, foi tocada no país inteiro, um sucesso amplamente divulgado pelas emissoras de rádio e apresentada no show de final de ano da TV Globo. A luta sensibilizava e ganhava a simpatia da população brasileira. Mostrava ser uma questão de tempo o fim da atividade baleeira, realizada no país unicamente no município de Lucena, litoral norte da Paraíba, pela Companhia de Pesca Norte do Brasil (Copesbra).

Na Paraíba - talvez o estado brasileiro onde mais se veiculou notícias relativas ao fim da "pesca da baleia" — o embate entre aqueles que defendiam a manutenção da atividade e aqueles contrários assumiu, em determinados momentos, contornos de drama. Os jornais de João Pessoa, capital do estado, foram os instrumentos de comunicação mais utilizados para se propagarem as principais ideias e concepçóes acerca desse acontecimento. A análise dos vários discursos que ajudaram a formar opinióes e percepçóes sobre a referida temática ajuda a entender como o problema foi tratado na época por segmentos da sociedade paraibana.

A partir do início da década de 1980, com o fortalecimento do movimento ambientalista brasileiro e com o aumento da simpatia de boa parte da opiniáo pública, a continuidade da

\footnotetext{
${ }^{1}$ CRIANÇAS apelam a Sarney e conseguem a lei que proíbe a matança de baleias no Brasil. O Momento, João Pessoa, 22-28 dez. 1985. p. 9.

${ }^{2}$ Lançada pela gravadora CBS Records, em 1981, a música As baleias foi a primeira canção de Roberto Carlos e Erasmo Carlos de cunho ecológico.
} 


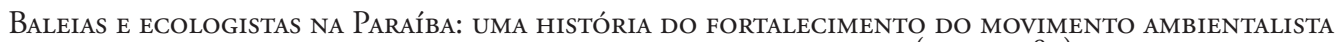
E O DEBATE SOBRE A CRISE DA ECONOMIA BALEEIRA (I970-I980)

Francisco Henrique Duarte Filho e José Otávio Aguiar

caça no litoral paraibano passou a ser objeto frequente de questionamentos éticos de grupos, entidades e cidadãos defensores das causas ecológicas em vários estados do país. ${ }^{3}$

O jornal $O$ Estado de S. Paulo, por exemplo, se manifestou no início da década de 1980 com indignação a respeito da manutenção da atividade baleeira no país:

É lamentável que o Brasil continue apoiando ou permitindo a caça às baleias em nossos mares. Quando se tem noção da influência direta desde animal dentro da cadeia ecológica marítima e consequentemente no equilíbrio ecológico mundial, seu valor econômico de caça desaparece. Não é concebível que interesses humanos manchem nossas praias e mares com sangue de mamíferos considerados com alto grau de inteligência. Aliás, por onde anda o espírito preservacionista que costumava fazer parte da inteligência humana? Existe atualmente uma cortina de interesses econômicos anestesiando o bom senso dos que tomam decisóes, prejudicando a ecologia, a vida, a segurança e tranquilidade do mundo. (...) A extinção das baleias não teria somente repercussóes regionais, como nos casos de poluição industrial, mas sim, teria consequências inevitáveis sobre a face da terra. Peço aos sensatos que pelo menos tentem evitar a extinção cruel das baleias, assim como, em longo prazo, de outras formas de vida terrestre, incluindo a humana. "S. O. S. — Salvemos as baleias" ${ }^{4}$

Como constatado pela leitura em alguns documentos da época, organizações civis ligadas às questóes ambientais deflagraram, principalmente através dos meios de comunicação, uma intensa campanha contra a atividade baleeira na Paraíba. Na vanguarda desse movimento, em nível regional, encontrava-se a Associação Paraibana dos Amigos da Natureza (Apan). Fundada em 1978 na cidade de Areia, no Brejo paraibano (em seguida começou a atuar também em João Pessoa), a entidade tinha como um dos seus objetivos sensibilizar a população paraibana e as autoridades do país à causa preservacionista. 5 Dessa forma, seus membros iniciaram um processo de luta para pressionar o governo brasileiro a instituir uma legislação federal que proibisse definitivamente a atividade baleeira em mares do Brasil. Um

\footnotetext{
${ }^{3}$ Durante a pesquisa nos documentos da Associação Paraibana de Amigos da Natureza (Apan) e no Núcleo de Documentação Histórica e Regional (NDHIR), ambos em João Pessoa, foi possível encontrar matérias e reportagens que tratavam do fim da atividade baleeira na Paraíba na década de 1980 em jornais de diversos estados e do distrito federal, entre eles: Diário de Pernambuco (PE); Jornal do Brasil (RJ); Folha de S.Paulo e O Estado de S. Paulo (SP); Zero Hora (RS) e Correio Braziliense (BrB).

${ }^{4}$ BLISKA, Antonella Cristina. Caça às baleias. O Estado de S. Paulo, São Paulo, 16 jan. 1981. p. 2.

${ }^{5}$ Embora enquadremos a luta contra a atividade baleeira na Paraíba na "causa preservacionista", nos discursos da época não se tem muito claro a diferença entre preservação e conservação de recursos naturais. Os membros do movimento contra a atividade baleeira em Lucena, principalmente aqueles ligados à Apan, chegam, em determinados momentos do embate, a defender em seu discurso a interdição da caça para que se possam avaliar os estoques e explorá-los de maneira "sustentável". Havia uma preocupação com o risco de extinção da espécie minke, uma vez que se achava que, se ela ocorresse realmente, comprometeria a exploração desse recurso pelas geraçóes futuras. Nesse sentido, o discurso se aproximava mais das tendências do conservacionismo.
} 
árduo caminho que culminaria, anos mais tarde, na assinatura, pelo presidente José Sarney, da Lei Federal no 7.643 no ano de 1987.

Além da Apan, que protagonizou a luta dos ambientalistas paraibanos contra a caça à baleia, documentos da época registraram igualmente o apoio declarado à causa das baleias por parte da Associação Pernambucana de Defesa da Natureza (Aspan — Recife), da União Nacional em Defesa das Baleias (Unde - São Paulo), do Greenpeace Brasil (sede em São Paulo), da Fundação Brasileira para a Conservação da Natureza (FBCN — Rio de Janeiro), da Associação Mineira de Defesa do Ambiente (Amda), da Associação Gaúcha de Proteção ao Ambiente Natural (Agapan), entre outras entidades.

Analisando os jornais da capital paraibana da década de 1980 (Correio da Paraíba, O Norte e $A$ União, principalmente), se pode encontrar uma quantidade expressiva de matérias e artigos que discutem a questão da manutenção ou desativação da economia baleeira no Brasil quanto aos seus efeitos sociais e econômicos sobre o município de Lucena. Os conflitos discursivos são geralmente polarizados, de um lado, por grupos políticos e empresariais, que defendiam a manutenção da caça à baleia por questóes econômicas e sociais. De outro, por ecologistas, professores universitários e simpatizantes da causa ambiental, contrários à exploração desse recurso natural com justificativas geralmente de cunho preservacionistas.

Folheando os principais jornais da época, verifica-se que praticamente todas as reportagens e matérias que fazem referência, com algum grau de aprofundamento, à atividade baleeira em Lucena sugerem algum tipo de preocupação com dois aspectos: as condiçôes de vida e de trabalho dos atores sociais (trabalhadores baleeiros, especialmente), que dependiam diretamente dessa atividade econômica para a sobrevivência; e a questão da preservação ambiental, colocada na perspectiva da defesa da vida dos mamíferos marinhos (baleias) que eram abatidos em escala comercial pela empresa japonesa.

Quanto aos possíveis efeitos negativos que poderiam ser gerados em Lucena e em cidades circunvizinhas - caso viesse mesmo a se confirmar o fim da caça à baleia no país empresários, sindicalistas e ambientalistas locais, independentemente de estarem associados à luta pela manutenção ou desativação dessa atividade extrativista, mostraram preocupação com o fator desemprego e com eventuais perdas de arrecadação que acarretariam prejuízos ao município de Lucena e à Paraíba.

Em meio à preocupação com o problema do desemprego iminente, outras possibilidades foram aventadas ao longo da década de 1980 para substituir a caça à baleia em Lucena por outra atividade que viabilizasse a economia local e absorvesse a mão de obra baleeira. Em evento da Sociedade Brasileira para o Progresso da Ciência (SBPC), realizado em Belo Horizonte, o professor Ângelo Machado, presidente da Comissão de Meio Ambiente da entidade, ao participar dos debates realizados no campus da Universidade Federal de Minas Gerais (UFMG), discorreu sobre uma possível alternativa à caça da baleia na Paraíba para suprir a mão de obra ociosa quando da paralisação da atividade baleeira. Segundo o professor, o 
problema poderia ser resolvido a partir da substituição do óleo de baleia, muito utilizado no Brasil em siderurgia, cosméticos, tingimento de couro, indústria têxtil e química, "por óleo de jojoba, uma planta adaptada a climas semiáridos e cuja cultura poderia absorver a mão de obra utilizada na caça à baleia". ${ }^{6}$

O jornal de João Pessoa que veiculou a declaração do professor Ângelo Machado no encontro da SBPC expôs também a posição do cientista sobre a decisão da Comissão Internacional de Baleeiros (CIB) de decretar uma moratória, a partir de 1986, permitindo apenas o abate de baleias para fins científicos. Quanto a essa questão, o pesquisador foi enfático ao denunciar uma tentativa de manobra de políticos paraibanos para que a atividade comercial continuasse na Paraíba protegida por este argumento: "Não podemos é ver brechas, sob prisma científico, e continuar a caça, pois o Brasil infelizmente não tem infraestrutura suficiente para pesquisa"?

Os debates e sugestóes para se resolver o problema baleeiro prosseguiam pela imprensa brasileira. Aproximadamente um mês após o encontro em Minas Gerais, o jornal $A$ União, também de João Pessoa, publicou uma matéria em que Guilherme Campelo Rabay, membro do Departamento Jurídico da Copesbra, descartava qualquer alternativa econômica à atividade baleeira: "Não existe outra alternativa [sic]. Se a pesca da baleia for proibida, a indústria fecha; a Copesbra para as suas atividades na Paraíba” ${ }^{8} \mathrm{O}$ jornal deu continuidade à matéria enfatizando que o fechamento da empresa significaria o desemprego para 326 pessoas ligadas diretamente ao processamento da baleia na fábrica pertencente ao grupo japonês instalada em Costinha. "Além desses operários, outros empregados que trabalham nos dois escritórios de venda em João Pessoa e Recife ficarão desempregados".

Os defensores do fim da atividade baleeira utilizaram-se dos meios possíveis para disseminar ideias e valores associados à sua causa. Os jornais paraibanos tornaram-se, muitas vezes, porta-vozes dos discursos dos ambientalistas que defendiam o fim da atividade baleeira no país. No contraponto do discurso ambientalista, por sua vez, se encontravam outras falas. O receio da perda do emprego e do sustento dos trabalhadores e suas famílias, que viviam da renda proporcionada pela atividade desenvolvida pela Copesbra, se manifestou igualmente nos meios de comunicação da época. A teia discursiva, que também envolveu políticos locais e segmentos da indústria paraibana, ia-se constituindo para dar sentido à existência de homens e mulheres que habitavam Lucena e adjacências, áreas de influência econômica da atividade baleeira e dos discursos difundidos na época.

\footnotetext{
${ }^{6}$ PROTESTO contra a Pesca da Baleia no SBPC — Professor alerta que o Brasil pode sofrer sançóes econômicas da CIB. Correio da Paraíba, 16 jul. 1985. Economia, p. 5.

${ }^{7}$ Id., p. 5.

${ }^{8}$ COPESBRA fecha se pesca parar - Empresa espera que projeto proibindo caça à baleia náo seja aprovado no Congresso. A União, João Pessoa, 31 ago. 1985, Economia, Caderno 7, p. 2.

${ }^{9}$ Ibid., p. 2.
} 
O trabalho de militância dos membros da Apan, seus discursos inflamados pelo fim da atividade baleeira, assim como o engajamento em uma frente nacional que passou a pressionar as autoridades em Brasília para a aprovação da lei repercutiram na sociedade da época. A opinião pública acolheu e apoiou as principais ideias difundidas pelo movimento ambientalista. Talvez por isso tenham prevalecido, no final dos anos de 1980, os interesses dos militantes da Apan e simpatizantes da causa baleeira. A luta vencida pelos ambientalistas foi coroada com a instituição da Lei Federal no 7.643/1987, que proibiu definitivamente a caça à baleia no país.

Algumas matérias sobre a atividade baleeira veiculadas em jornais de circulação naciona ${ }^{10}$ discorreram sobre a participação da população na causa conservacionista defendida pelos ativistas paraibanos. Jornais do Rio de Janeiro, Rio Grande do Sul, Brasília e São Paulo, especialmente, estiveram à frente do movimento contra a caça à baleia no país. A imprensa escrita se fazia presente e o movimento ganhava repercussão nacional.

Em matéria noticiada pelo jornal $O$ Norte, ${ }^{11}$ discorre-se sobre a formulação — durante o II Encontro Nordestino de Ecologia, realizado de 14 a 17 do mês de janeiro de 1981, em Recife - de um documento de repúdio ao presidente da República, João Batista de Oliveira Figueiredo, pela prorrogaçáo da atividade baleeira no litoral paraibano. Um grupo de 25 pessoas, entre ecologistas, professores universitários e estudantes paraibanos, esteve presente ao evento e se manifestou, de forma organizada e pacífica, contra a manutenção da atividade de caça em Lucena. Alguns representantes do movimento ambientalista paraibano, recém-organizado, estavam presentes ao evento, o que demonstra o processo de mobilizaçáo desse movimento associado ao fim da caça à baleia.

Os textos jornalísticos que discorriam sobre a atuação dos ambientalistas paraibanos sugerem que o trabalho de mobilização dos membros da Apan pelo fim da atividade baleeira extrapolava os limites geográficos da Paraíba. Matérias publicadas nos jornais da época demonstram que, por entenderem que o objetivo maior era pela instituição de uma lei federal, os ativistas da Apan também se faziam presentes em eventos políticos e acadêmicos ${ }^{12}$ regionais e nacionais, onde passaram a reafirmar seu protesto contra o que eles consideravam um massacre às baleias que, ao migrarem anualmente para o litoral da Paraíba, eram abatidas às centenas pelos caçadores locais sob coordenação da Companhia de Pesca Norte do Brasil.

Em entrevista concedida ao jornal O Norte, de 20 de janeiro de 1981, Paula Frassinete Lins Duarte, na época professora do curso de biologia da Universidade Federal da Paraíba (UFPB) e membro da Apan, que se fazia presente ao evento organizado no litoral de Pernambuco, enfatizou a necessidade de suspensão urgente da atividade baleeira em razão do

\footnotetext{
${ }^{10}$ Entre os jornais de circulação nacional que deram ênfase à questão baleeira, principalmente no tocante ao projeto do deputado Gastone Righi proibindo a caça à baleia no país, podem ser citados: Folha de S.Paulo, Correio Braziliense, O Estado de S. Paulo, Zero Hora e O Globo.

${ }^{11}$ HOJE tem vigília. O Norte, 4 jul. 1981. p. 3.

${ }^{12}$ ECÓLOGOS firmam protesto contra presidente por prorrogar caça à baleia, O Norte, 20 jan. 1981, p. 1.
} 


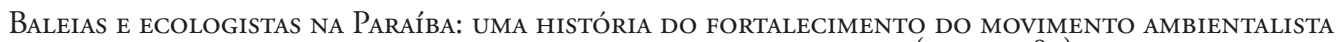
E O DEBATE SOBRE A CRISE DA ECONOMIA BALEEIRA (I970-I980)

Francisco Henrique Duarte Filho e José Otávio Aguiar

receio da extinção das espécies e da importância de se permitir que os animais pudessem se reproduzir no litoral paraibano sem serem molestados ou mortos por caçadores:

As baleias caçadas no litoral paraibano escolhem estas águas para o acasalamento; e se são capturadas nesse período, são impedidas de reproduzirem-se, ocasionando, assim, um decréscimo em número. Uma prova desta redução: a Copesbra - empresa responsável pela pesca - há dois anos que náo consegue atingir a cota estipulada pela Associaçáo Internacional da Baleia. ${ }^{13}$

O discurso da professora e ambientalista Paula Frassinete Lins Duarte, que em certa medida sugere um ar de comoção, foi endossado por um dos grandes ecologistas brasileiros presentes ao evento, Joáo de Vasconcelos Sobrinho. Convidado para uma palestra no mesmo evento, o professor pernambucano ao se referir a caça à baleia falou sobre a necessidade de se estabelecer a proibição da atividade no Brasil. Vasconcelos Sobrinho abriu um espaço em sua palestra e fez o seguinte comentário sobre a morte dos cetáceos em águas do litoral paraibano, o qual foi destaque no Diário de Pernambuco do dia 15 de janeiro de 1981:

(...) nas águas quentes do Nordeste a baleia tem sua área de acasalamento. Para todas as espécies, as áreas de acasalamento são santuários de preservação, que deveriam merecer todo o amparo de homens civilizados. O Nordeste tem a responsabilidade por zelar por suas águas territoriais, como faríamos se fôssemos menos bárbaros. ${ }^{14}$

Como se pode inferir da fala do professor Vasconcelos e da própria Paula Frassinete, um dos argumentos mais fortes utilizados pelos ecologistas que lutavam contra a caça à baleia nas águas jurisdicionais brasileiras era o da importância e necessidade de os cetáceos poderem acasalar e se reproduzir, sem se tornarem alvos de caçadores. Os depoimentos dos professores identificam-se com características do discurso ambientalista, na corrente conservacionista, que tomava corpo nos meios intelectuais brasileiros a partir de conceitos e concepçóes associados ao desenvolvimento sustentável em construçáo na segunda metade do século passado. A própria preocupação presente nos encontros mundiais sobre a preservação da vida no planeta, ocorridos a partir dos anos $1970,{ }^{15}$ corrobora a tese de que mudanças importantes em relação ao tratamento humano para com o meio ambiente se tornariam, a partir de então, uma realidade em praticamente todos os países ocidentais.

\footnotetext{
${ }^{13}$ Ibid., p. 2.

${ }^{14}$ FALSOS argumentos basearam liberação da pesca da baleia. Diário de Pernambuco, Recife, 15 jan. 1981. p. 1.

${ }^{15}$ Entre os encontros internacionais organizados pela ONU para se discutir os problemas socioambientais, dois se destacam em razão de sua importância para os destinos do planeta: Conferência das Nações Unidas sobre o Meio Ambiente Humano — Estocolmo (1972) e a Conferência das Naçóes Unidas sobre Meio Ambiente e Desenvolvimento (Cnumad) — Rio de Janeiro, 1992.
} 
Em relação aos discursos, se pode constatar que foram vários os argumentos utilizados pelos ambientalistas nos jornais da década de 1980 para justificar a necessidade de se pôr fim à caça à baleia no Brasil. Entre os mais utilizados, pode ser destacada a crítica frequentemente dirigida ao fato de que esse recurso natural, explorado de maneira predatória no litoral do país unicamente no município de Lucena, estado da Paraíba, servia principalmente aos interesses econômicos de estrangeiros, particularmente dos japoneses ligados à empresa Nippon Reizo Kabushiki Kaisha, multinacional do ramo de pescados com matriz na cidade de Tóquio. Empresa de grande porte que detinha o monopólio sobre os produtos baleeiros explorados na Paraíba, com destaque para a carne tipo exportação. Os ambientalistas denunciavam, entre outras coisas, que através da Copesbra os japoneses destinavam os chamados "cortes especiais" da carne de baleia para revenda (a preços elevados) no mercado daquele país, auferindo vultosos lucros com a atividade, em detrimento das questionáveis condiçóes de vida e de trabalho da população baleeira de Lucena, principal mão de obra geradora da riqueza para os empresários japoneses.

Para os representantes da Apan e simpatizantes da causa, a caça à baleia deveria ser proibida o mais rapidamente possível, uma vez que a continuação dessa atividade poderia levar a baleia minke à extinção, assim como teria ocorrido com outras espécies que foram caçadas à exaustão ao longo das extensas faixas do litoral brasileiro em períodos anteriores. $\mathrm{O}$ histórico da caça na Paraíba, realizada desde o início do século XX, era utilizado pelos ambientalistas para demonstrar o decréscimo populacional das espécies caçadas há décadas em águas do litoral norte da Paraíba. Ademais — acrescentavam os ambientalistas —, havia indícios de que as baleias fêmeas estavam sendo mortas em maior número do que os machos, o que poderia comprometer ainda mais a perpetuação da espécie explorada.

Embora algumas vezes acusados de desconhecer a biologia comportamental e reprodutiva dos cetáceos, ${ }^{16}$ os ambientalistas da Apan não evidenciavam preocupação com as tentativas dos representantes da Copesbra em desqualificar o discurso conservacionista. Geralmente com formação em biologia, os ambientalistas demonstravam que tinham conhecimento do desaparecimento de algumas espécies das águas brasileiras em razão da caça predatória praticada em outros estados da federação, principalmente no Rio de Janeiro e em São Paulo, uma vez que entidades de proteção às baleias com sede nesses dois estados brasileiros também socializavam conhecimentos e compartilhavam da luta da entidade paraibana pelo fim da atividade baleeira no Brasil.

Ambientalistas reivindicavam igualmente a suspensão imediata da caça com argumento de que estudos científicos deveriam ser promovidos e divulgados pelas instituiçóes de pesquisa para comprovar a viabilidade e a racionalidade da exploração das baleias caçadas

\footnotetext{
${ }^{16}$ O jornal O Norte, de 3 de setembro de 1985, publicou matéria com o título: "Copesbra vê fantasia em declaração de dirigente", p. 2, acusando os dirigentes da Apan de desconhecimento sobre a biologia e ecologia dos cetáceos, particularmente da espécie minke que era caçada na Paraíba.
} 


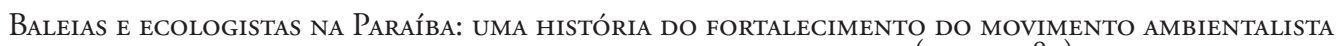
E O DEBATE SOBRE A CRISE DA ECONOMIA BALEEIRA (I970-I980)

Francisco Henrique Duarte Filho e José Otávio Aguiar

na Paraíba. Alegavam os conservacionistas que as baleias minke, caçadas em período fértil, poderiam entrar na lista de animais em extinção pela falta de regulamentação e controle da caça no país.

Em matéria publicada pelo jornal $O$ Norte, no dia 18 de maio de 1981, o ecologista e professor da Universidade Federal da Paraíba (UFPB), Antonio Moacyr Madruga, assumiu posição favorável à paralisação da exploração baleeira no Brasil por motivos claramente conservacionistas. Para o referido professor, as pesquisas da época não comprovavam a viabilidade e a racionalidade econômica da atividade:

Sou pela paralisação da atividade baleeira, tendo em vista que os estudos até entáo realizados demonstraram que a Copesbra realiza suas atividades sem a comprovação de ser esta atividade explorada cientificamente, à medida que não houve avaliação dos estoques iniciais nem dos atuais de baleias na área, não se podendo limitar as estimativas de apreensão e, na análise histórica nota-se o desaparecimento de outras espécies do cetáceo, antes alvo central das atividades baleeiras da Copesbra, é o caso a ser citado das espadartes e cachalotes. ${ }^{17}$

A preocupação do professor Madruga quanto ao estado de vulnerabilidade de algumas espécies de baleias, manifestada no final de seu depoimento, se mostra pertinente considerando a depleção secular desse recurso natural provocada por seres humanos. As espécies espadarte, jubarte e cachalote, de tamanho maior e economicamente mais viáveis que a minke, se constituíram até a década de 1960 nos principais alvos dos caçadores na Paraíba. $\mathrm{Na}$ ótica dos ambientalistas, a exploração desordenada desses animais no litoral paraibano teria contribuído para o declínio dessas populaçôes, notadamente a partir da segunda metade do século XX.

Numa perspectiva econômica mais global, a constatação de Antonio Moacyr Madruga encontra ressonância no fato de que, em praticamente todos os mares onde a caça comercial e industrial da baleia foi praticada, inclusive pelos países que mais tarde viriam a se tornar membros da IWC, as espécies mais produtivas foram caçadas ao extremo. O histórico da caça predatória e a consequente necessidade de estabelecer limites para a captura dos animais, a partir da Convenção para Regulamentação da Pesca da Baleia em 1946, lançam luz aos argumentos expostos pelo professor da UFPB quando sai em defesa da suspensáo imediata da atividade. No próprio preâmbulo da Convenção de 1946 chancelada pelo governo dos Estados Unidos da América, se apresentam algumas razóes pelas quais se tornou imperativa a necessidade de se regulamentar mundialmente a atividade de caça à baleia. Entre elas, considerou-se o fato de que:

\footnotetext{
${ }^{17}$ BALEIA: um problema cada vez mais sério no Nordeste. O Norte, João Pessoa, 1981. p. 2.
} 
Baleias e ECOlogistas na Paraíba: uma história do FORTAlecimento do MOVimento ambientalista E O DEBATE SOBRE A CRISE DA ECONOMIA BALEEIRA (I970-I980)

Francisco Henrique Duarte Filho e José Otávio Aguiar

(...) desde seu início, a pesca da baleia deu margem a uma exploração excessiva de uma zona após outra e à destruição imoderada de uma espécie após outra, ao ponto de se tornar essencial a proteção a todas as espécies das baleias contra o prolongamento de abuso dessa natureza. ${ }^{18}$

Os argumentos, apresentados pelo professor Madruga em defesa da paralisação da atividade baleeira, considerando o contexto da época, sugerem coerência. Realmente, não havia muitos incentivos aos estudos científicos ${ }^{19}$ à época no país para que se demonstrasse que a exploração baleeira estava sendo feita racionalmente, ou seja, dentro de limites ecológicos e de sustentabilidade ambiental. Aliás, dada a dificuldade ainda hoje de se observar e monitorar grandes espécies migratórias como algumas espécies de baleias, os estudiosos encontram enormes dificuldades em estudar animais com características tão diversas. Alguns estudos feitos por biólogos e oceanógrafos, por exemplo, já monitoraram baleias que nadaram pelos oceanos cerca de 10 mil quilômetros em um ano. Alguns espécimes migratórios que são identificados e monitorados em determinadas áreas oceânicas podem desaparecer com certa facilidade do controle dos cientistas. Fato que demonstra as dificuldades de se aprofundar estudos biológicos e ecológicos sobre esses mamíferos marinhos.

Quanto ao que o professor denominou de “análise histórica” para a realidade da Paraíba, há de se considerar que realmente os números disponíveis na época, inclusive pela própria empresa que monopolizava a atividade baleeira, já apontavam para a gradativa escassez de algumas espécies caçadas em Lucena. Nos dados reunidos a partir das planilhas da própria Copesbra (tabela 1), pode-se verificar que, ao longo da década de 1960 e início dos anos 1970, o número de baleias-espadartes (Balaenopteraborealis) e cachalotes (Physeter macrocephalus) abatidos foi reduzido consideravelmente. Todavia, se nos anos 1960 essas espécies se constituíram nas mais capturadas pelos japoneses, foram, no entanto, sendo substituídas por outra espécie, a baleia minke (Balaenoptera bonaerensis), encontrada com certa abundância na porção mais oriental do Atlântico Sul, área de atuação da estação baleeira pertencente aos japoneses.

\footnotetext{
${ }^{18}$ INTERNATIONAL CONVENTION FOR THE REGULATION OF WHALING. Adopted in Washington, USA, on 2 December 1946, p. 1. Disponível em: <http://iwcoffice.org/commission/convention. htm>. Acesso em: 15 jan. 2011.

${ }^{19} \mathrm{Um}$ fato que ilustra bem as dificuldades, principalmente financeiras e logísticas, para se realizar pesquisas sobre os cetáceos na época da caça à baleia pode ser verificado no descontentamento assumido publicamente pelo professor Kandar Valipuran Singarajah, pesquisador inglês de descendência indiana, que desenvolvia na Universidade Federal da Paraíba, no início da década de 1980, um estudo sobre o sistema nervoso central e o comportamento da espécie minke. Em reportagem do jornalista José Carlos dos Anjos, intitulada "Docente estuda a baleia minke”, publicada no jornal A União, de João Pessoa, em 4 de dezembro de 1983, p. 2, expóe-se a insatisfação do referido professor com a falta de apoio para o andamento de suas pesquisas naquela instituição.
} 
Baleias e ECOlogistas na Paraíba: uma história do FORTAlecimento do MOVimento ambientalista E O DEBATE SOBRE A CRISE DA ECONOMIA BALEEIRA (I970-I980)

Francisco Henrique Duarte Filho e José Otávio Aguiar

Tabela 1

Captura anual das baleias-espadartes, cachalotes e minkes no litoral da Paraíba — década de referência: 1960

\begin{tabular}{|c|c|c|c|}
\hline Ano & Espadarte & Cachalote & Minke \\
\hline 1960 & 750 & 29 & - \\
\hline 1961 & 957 & 102 & - \\
\hline 1962 & 610 & 85 & 2 \\
\hline 1963 & 346 & 42 & 44 \\
\hline 1964 & 256 & 4 & 68 \\
\hline 1965 & 149 & 13 & 352 \\
\hline 1966 & 72 & 24 & 488 \\
\hline 1967 & 49 & 20 & 456 \\
\hline 1968 & 58 & 39 & 617 \\
\hline 1969 & 56 & 75 & 701 \\
\hline 1970 & 23 & 76 & 2.728 \\
\hline Total & 3.326 & 509 & Par \\
\hline
\end{tabular}

Fonte: DUARTE FILHO, F. H.; AGUIAR, J. O. História ambiental e atividade baleeira na Paraíba: algumas interrogações. In: RODRIGUES, Andre Figueiredo et al. (Org.). Natureza e cultura nos dominios de Clio: história, meio ambiente e questóes étnicas. Campina Grande: EDUFCG, 2012.

Sem maiores explicaçóes por parte daqueles que administravam a caça no país, a carne e os derivados dessa nova espécie passaram, a partir de meados da década de 1960, a ser processados e contabilizados nas planilhas e balancetes da Copesbra.

Embora as baleias minke fossem menores (também chamadas de baleias anãs), eram encontradas em grande número nas águas do litoral norte da Paraíba entre os meses de julho e dezembro. Esses detalhes ajudam a explicar o fato de que, para alcançar a quantidade de carne e derivados das décadas anteriores, quando se abatiam espécies maiores, era necessário capturar um número maior de animais no período de caça. Assim, as duas espécies maiores e mais atraentes economicamente, citadas anteriormente, praticamente desapareceram das anotações registradas pela Companhia de Pesca Norte do Brasil no decorrer dos anos de 1970 e 1980.

O professor Madruga levantou também questionamentos sobre os problemas sociais e econômicos que envolviam a atividade baleeira em Lucena. Um desses problemas suscitados fazia menção às relaçóes de trabalho, à exploração da mão de obra dos trabalhadores, submetidos a várias horas de serviços no mar e no processamento dos derivados em troca de remuneraçóes diárias consideradas muito baixas. ${ }^{20}$ Inclusive fez denúncia pública utilizando

\footnotetext{
${ }^{20}$ Alguns depoimentos colhidos entre trabalhadores remanescentes da atividade baleeira, entre eles o do sr. Severino Freire Dias, na época presidente do sindicato dos baleeiros, depóem contra essa afirmação. Consideram, ao contrário, que a Copesbra pagava bem aos seus trabalhadores. NEVES, Severino Freire. 60 anos. Depoimento novembro de 2011, Praia de Costinha, Lucena (PB). Entrevistador: Francisco Henrique Duarte Filho. Acervo do autor.
} 
os meios de comunicação da época sobre desníveis salariais ${ }^{21}$ entre brasileiros e japoneses que exerciam a mesma função dentro da empresa.

A tabela 2, construída a partir dos dados disponibilizados por Madruga, ${ }^{22}$ tendo o ano de 1979 como referência, obtidos a partir da folha de pagamento dos funcionários da empresa japonesa, proporciona uma visão elucidativa da diferenciação entre os salários pagos pela Copesbra a trabalhadores japoneses e brasileiros.

Tabela 2

Número de empregados fixos e faixa salarial - Copesbra, 1979

\begin{tabular}{|c|c|c|}
\hline Faixa salarial, em Cr\$ & Brasileiros & Japoneses \\
\hline$<5.000,00$ & 123 & 1 \\
\hline $5.000,00 \mathrm{a} 10.000,00$ & 8 & 2 \\
\hline$+10.000,00$ & 3 & 2 \\
\hline$+20.000,00$ & - & 7 \\
\hline$+30.000,00$ & - & 4 \\
\hline$+40.000,00$ & - & 2 \\
\hline$+50.000,00$ & - & 2 \\
\hline Total & 134 & 20 \\
\hline
\end{tabular}

Fonte: MADRUGA, A. M. A questão da baleia, op. cit. p. 106.

Como se pode observar, de todos os empregados brasileiros constantes nas folhas de pagamento da Copesbra no ano de 1979, apenas três funcionários ganhavam mais de $10 \mathrm{mil}$ cruzeiros mensais: cerca de quatro salários mínimos na época. Já oito funcionários brasileiros ganhavam entre 5 e 10 mil cruzeiros e o restante menos de 5 mil cruzeiros mensais. ${ }^{23}$

Sobre esta questão, o professor Moacyr Madruga ainda enfatizou que os trabalhadores da empresa japonesa desenvolviam suas atividades, dependendo da época do ano e da demanda pelos produtos baleeiros, entre 16 e 18 horas por dia, quando a legislaçáo brasileira da época estipulava o número de horas trabalhadas em 48 horas semanais. Discorrendo sobre as relaçóes de trabalho no âmbito da empresa japonesa, o referido professor teceu as seguintes consideraçōes:

\footnotetext{
${ }^{21}$ Realmente observa-se, em praticamente todos os depoimentos analisados, que os depoentes reafirmam que os salários pagos para os japoneses eram maiores do que os pagos aos brasileiros exercendo a mesma função dentro da empresa.

${ }^{22}$ MADRUGA, A. M. A questão da baleia: da luta ecológica à exploração humana. In: Cadernos de Estudos Regionais. O Porto de Cabedelo e a pesca da baleia - Série Monografia 2. João Pessoa: UFPB/NDIHR-CNPq. Ano 3, n. 3, 1980.

${ }^{23}$ Considerando que, em maio de 1979, o salário mínimo era de Cr\$2.268,00, sugere-se que a maioria dos trabalhadores brasileiros a serviço da Copesbra que tinham carteira assinada ganhava em média dois salários mínimos, o que foi confirmado pelos depoimentos dos ex-trabalhadores baleeiros que foram entrevistados para a presente pesquisa e pelos registros constantes de algumas carteiras de trabalho verificadas.
} 


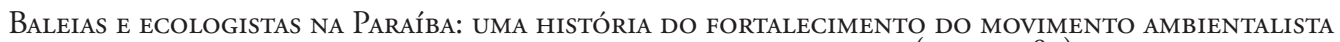
E O DEBATE SOBRE A CRISE DA ECONOMIA BALEEIRA (I970-I980)

Francisco Henrique Duarte Filho e José Otávio Aguiar

Ao realizarmos uma análise conjunta da história da atividade baleeira, principalmente no Brasil, enfocando os problemas da região e a atividade atual, verificamos que se o povo que nela trabalha não é mais o escravo dos tempos passados, o sistema de assalariamento que se emprega visa única e exclusivamente os interesses da multinacional que realiza essa atividade. Empresa essa que exerce uma verdadeira opressão econômica, social e até mesmo cultural sobre a população local, uma vez que os representantes da multinacional, no caso a Nippon Reizo KK, de Tóquio, poderosa firma de pescados e frios do Japão, realizam uma verdadeira agressão à população local, vivendo como se essa não existisse, formando um verdadeiro quisto detentor do dinheiro e do poder, influindo na política e condicionando, das mais variadas formas, o viver daquela população. ${ }^{24}$

As horas excessivas de trabalho da tripulação do navio baleeiro também foram objeto de observação de um estudioso da temática. Segundo depoimento do professor Singarajah, ${ }^{25}$ em dia de atividade considerada normal, as operaçóes de caça da empresa japonesa começavam antes do amanhecer. Por volta de 4 h o navio Cabo Branco partia do Porto de Cabedelo rumo à captura das baleias para somente retornar no final do dia, por volta das $18 \mathrm{~h}$, quando a pouca visibilidade provocada pelo pôr do sol comprometia as operaçóes de caça do referido baleeiro.

Em algumas matérias e entrevistas de pessoas ligadas à luta pelo fim da caça à baleia, principalmente ambientalistas da Apan, sob o argumento de que a maior parte dos empregos gerados pela Copesbra era sazonal, e mesmo no período mais intenso da caça, chamado de período de "safra" (de julho a dezembro), pouco mais de trezentos pais de família trabalhavam e viviam diretamente da atividade. Alegavam os críticos que outras oportunidades de emprego e renda menos degradantes poderiam ser fomentadas no município de Lucena, como alternativa ao fim iminente dessa atividade econômica na região.

\section{Dados econômicos e a retórica do desenvolvimento sustentável: argumentos em defesa e contra a "pesca da baleia" na Paraíba}

O discurso dos ambientalistas e simpatizantes da causa ambiental não gozava de unanimidade no contexto do referido debate. Defendendo a manutenção da caça comercial encontravam-se empresários e representantes sindicais ligados à atividade baleeira, alguns parlamentares paraibanos e membros de famílias dos trabalhadores de Lucena que dependiam direta ou indiretamente dessa atividade para obtenção de alimentos e recursos financeiros. No contraponto do discurso ecológico, analisado anteriormente, o principal argumento uti-

\footnotetext{
${ }^{24}$ MADRUGA, A. M. A questão da baleia, op. cit. p. 70.

${ }^{25}$ DOCENTE estuda a baleia minke. A União, João Pessoa, 4 dez. 1983. p. 2.
} 
lizado em favor da manutenção da caça à baleia em Lucena era o da empregabilidade, da manutenção das proteínas obtidas a partir da carne de baleia para a comunidade carente do Nordeste e da importância dos impostos obtidos pelo poder municipal e estadual quando da exportação dos produtos baleeiros para o Japão.

Os defensores da caça à baleia argumentavam que, se a atividade chegasse mesmo a ser desativada, centenas de famílias iriam sofrer as consequências do desemprego, da fome e da miséria. Além de que o município e o estado da Paraíba iriam perder somas consideráveis em impostos e tributos, principalmente em divisas de exportação, ICM e contribuição previdenciária. Tributos e impostos estes que eram gerados pela atividade baleeira praticada há décadas na Paraíba. Um jornal de João Pessoa do início dos anos 1980 revelava uma das linhas de argumento utilizada pelos defensores desse tipo de extrativismo animal praticado na Paraíba:

A pesca da baleia proporcionará, este ano, à Paraíba e ao Nordeste: 820 toneladas de óleo de baleia para indústria nacional; 1.263 toneladas de carne para consumo interno; 905 toneladas de carne congelada; 440 toneladas de farinhas orgânicas; 410 empregos diretos e 3.000 indiretos; Cr\$ 65 milhôes em divisas; Cr\$ 75 milhões em salários; Cr\$27 milhôes em ICM; Cr\$ 13 milhões em contribuiçôes previdenciárias. Deixando de pescar nada disso existirá.... ${ }^{26}$

Os números divulgados pela Copesbra ao longo dos anos de 1980 nos jornais de Joáo Pessoa alimentaram a polêmica acerca da importância social e econômica que o empreendimento baleeiro possuía para a região e para o estado da Paraíba. Não foram poucos os artigos publicados pelos jornais da época fazendo referência aos benefícios sociais e econômicos gerados pela empresa baleeira.

Entre os dados constantemente divulgados estava o quantitativo de trabalhadores que caçavam e processavam os produtos baleeiros no litoral paraibano. A empresa se utilizou inúmeras vezes dos jornais que circulavam na regiâo para confirmar que, se realmente a caça à baleia fosse proibida, a fábrica seria fechada e centenas de pais de famílias seriam lançados ao desemprego. Todavia, as matérias apresentaram o quantitativo de trabalhadores sempre instável ao longo do tempo e, pelo que se pode deduzir, os números que eram apresentados pela imprensa da época variavam de acordo com os interesses dos responsáveis por sua divulgação. Em depoimentos analisados nos artigos de jornais entre 1980 e 1986, período que abrange o maior número de matérias sobre essa discussão, encontraram-se divergências bem significativas quanto ao número de trabalhadores efetivamente envolvidos com a caça à baleia na costa paraibana:

(...) é na cidade paraibana de Lucena que se encontra o único foco brasileiro de pesca de baleia, representando pela Companhia de Pesca Norte do Brasil — Copesbras — de capital japonês.

\footnotetext{
${ }^{26}$ TIRANDO do mar o que falta na terra. Correio da Paraíba, João Pessoa, 5 ago. 1980. Geral, p. 11.
} 


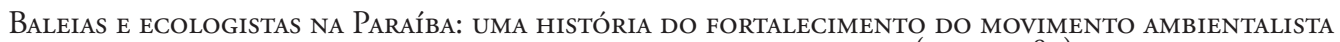
E O DEBATE SOBRE A CRISE DA ECONOMIA BALEEIRA (I 970-I980)

Francisco Henrique Duarte Filho e José Otávio Aguiar

Ela emprega cerca de 300 pessoas da cidade e a Sudepe, embora ache que a captura de um determinado número de baleias para pesquisa deva ser mantido, começa a acionar um antigo programa de atividades alternativas para a população de Lucena. Através de convênio com a Sudene, o superintendente da Sudepe, Petronilo Santa Cruz, estuda a possibilidade de aplicar ali o programa de pesca artesanal (sobretudo atum e algas), comprovadamente rentável para a população. ${ }^{27}$ (grifamos)

Além dos números desencontrados ${ }^{28}$ que procuravam demonstrar a importância social e econômica da atividade baleeira para o município de Lucena e para a Paraíba, não faltaram, somando-se a esses dados, argumentos no mínimo inusitados que procuravam justificar a caça às baleias como "necessária”, uma vez que se acreditava que esses animais "representavam uma ameaça à espécie humana”. Merece ser mencionada uma matéria veiculada no jornal O Norte, de 25 de fevereiro de 1980, assinada por um "ecologista" paraibano de nome Balduíno Lélis de Farias, nascido em Taperoá, que defendia não apenas a manutenção da caça às baleias, mas a própria extinção das mesmas como "benéfica à natureza".

O referido "pesquisador", como é chamado pelo jornal que publicou a matéria, parte do princípio que a baleia "é prejudicial ao homem...", uma vez que ela contribui para o desequilíbrio ecológico quando devora em curto espaço de tempo grande quantidade de peixes, concorrendo com os seres humanos na busca de alimentos no ambiente marinho. $\mathrm{O}$ mesmo fundamentou sua opinião utilizando-se dos seguintes argumentos:

Ela (a baleia) está fora de tempo e de espaço. Sua estrutura física está superada. Ela era da terra e fugiu para o mar e lá, evidentemente, dispunha de uma grande quantidade de alimento sem ninguém para competir, o que facilitou seu desenvolvimento (...). A baleia é um mamífero. Ela come exatamente o que nós comemos, o peixe. A baleia come atualmente 420 toneladas de peixes por dia, o que representa a considerável soma de 147 milhóes de toneladas por ano. Se deixarmos esta baleia continuar se multiplicando na base de 420 mil por ano — vamos dizer que somente metade destas baleias realmente fecundasse - então teríamos 200 mil baleias por ano, o que em dez anos seriam dois milhóes de baleias. Seriam dois milhóes de toneladas de peixes por dia e 730 milhóes de toneladas por ano. É, sem dúvida, um preço muito alto que a Humanidade irá pagar por um animal que não chega a representar quase nada ou nenhum

\footnotetext{
${ }^{27}$ AZEREDO, Zenaide. PB quer continuar caçando baleias. O Estado de S. Paulo, 7 jul. 1985. Caderno Ambiente, p. 3.

${ }^{28}$ Nos documentos pesquisados dos anos 1970 e 1980 (revistas, jornais, relatórios da Copesbra e artigos científicos) não há consenso quanto ao número de empregados diretamente ligados à atividade baleeira. Falam em trezentos, quatrocentos e até mil trabalhadores diretos. O que as fontes pesquisadas deixam subentendido é que o número de trabalhadores variava de acordo com as cotas de abate que eram estabelecidas por temporada de caça. Como as cotas variavam anualmente, o número de trabalhadores, em sua maioria sazonal, parece acompanhar essa variação.
} 


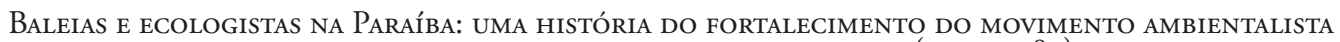
E O DEBATE SOBRE A CRISE DA ECONOMIA BALEEIRA (I970-I980)

Francisco Henrique Duarte Filho e José Otávio Aguiar

equilíbrio ecológico. Daí por que afirmo que ela é um predador e um perigoso concorrente do homem em termos de sobrevivência. ${ }^{29}$

Os argumentos de Balduíno Lélis de Farias parecem carecer de sustentação científica. Senão no todo, pelo menos em relação ao fato de querer estabelecer generalizações quanto ao comportamento e hábitos alimentares desses animais, como se somente existisse uma espécie de baleia. Hoje se tem conhecimento de que existem pelo menos 76 espécies e dezessete subespécies, com características e padrôes de comportamento tão distintos que jamais se poderiam usar tais generalizaçôes, como as que foram utilizadas pelo referido professor para caracterizá-las quanto aos hábitos alimentares e uma eventual concorrência com os seres humanos por recursos marinhos.

Quanto à afirmação do "pesquisador" de que a humanidade irá pagar um preço muito alto "por um animal que não chega a representar quase nada ou nenhum equilíbrio ecológico", parece ainda mais absurda. Para efeito de demonstrar aspectos relacionados ao comportamento biológico das baleias e sua importância para a manutenção do equilíbrio ecológico, basta destacar que estudos recentes constataram que o ferro presente nas grandes quantidades de fezes que esses animais expelem no mar exerce um papel importante na cadeia alimentar, na medida em que passa a ser utilizado como fonte de alimento para os fitoplânctons, seres microscópicos que servem, por sua vez, como alimento para uma infinidade de outras espécies, contribuindo para manter a estabilidade ecossistêmica:

Biólogos australianos calcularam que as cerca de 12 mil baleias cachalotes do Oceano Austral defecam, cada uma, cerca de 50 toneladas de ferro no mar a cada ano, após digerirem os peixes e lulas, que são a base de sua dieta. O ferro é um excelente alimento para o fitoplâncton plantas marinhas que vivem perto da superfície do oceano e que tiram $\mathrm{CO}_{2}$ da atmosfera através da fotossíntese. O Oceano Austral é rico em nitrogênio e pobre em ferro, que é essencial ao fitoplâncton. Como resultado desta fertilização orgânica do ambiente marinho, as baleias ajudam a remover 400.000 toneladas de carbono a cada ano, duas vezes mais que as 200 mil toneladas de $\mathrm{CO}_{2}$ que elas liberam através da expiração. Comparativamente, 200 mil toneladas de $\mathrm{CO}_{2}$ equivalem às emissóes de quase 40.000 carros de passageiros, segundo estimativas do site da agência ambiental americana (EPA). Segundo a EPA, com base em um cálculo feito em 2005, um veículo de passageiros que roda 20 mil quilômetros por ano emite mais de cinco toneladas de $\mathrm{CO}_{2}$ ou carbono equivalente ao ano. As fezes das baleias são muito eficazes porque são liberadas em estado líquido e perto da superfície marinha, antes de os mamíferos mergulharem (...). Antes da pesca industrial de baleias, a população da espécie era cerca de 10 vezes maior, o que significa que dois milhóes de toneladas de $\mathrm{CO}_{2}$ eram removidas anualmente. ${ }^{30}$ (grifamos)

\footnotetext{
${ }^{29}$ EXTINÇÃO da baleia vista como benéfica à natureza. O Norte, João Pessoa, 25 fev. 1980. Geral, p. 5.

${ }^{30}$ FEZES de baleias ajudam no combate ao aquecimento global. Revista Exame Online, 15 out. 2010. Disponível em: <http://exame.abril.com.br/economia/meio-ambiente-e-energia/noticias/fezes-baleia-ajudam->.
} 
O estudo mencionado sugeriu que o fato de os fitoplânctons retirarem da atmosfera, por meio do processo de fotossíntese, uma quantidade significativa de $\mathrm{CO}_{2}$, um dos principais gases responsáveis pelo aquecimento do planeta, as baleias acabam contribuindo para reduzir o que alguns estudiosos denominaram de "efeito estufa" ${ }^{31} \mathrm{Ou}$ seja, as baleias, assim como milhares de outros animais marinhos exercem, cada qual à sua maneira, importantes funçôes na estabilidade dos sistemas ecológicos.

Entrevistas e depoimentos publicados pelos principais jornais da época, portanto, procuraram manifestar opinióes polêmicas e sentimentos contraditórios que tomavam de impulso a opinião pública paraibana. Em outra matéria publicada em jornal da capital da Paraíba, em dezembro de 1987, verifica-se o descontentamento do presidente do Sindicato dos Trabalhadores na Indústria da Pesca e da Extração do Óleo da Baleia de Lucena, Severino Freire das Neves e de Guilherme Rabay, Assessor Jurídico da Copesbra, quando da notícia de que o Senado brasileiro havia aprovado o Projeto de Lei que proibia definitivamente a atividade baleeira em águas jurisdicionais brasileiras. O jornal pessoense destacou a seguinte observação do sindicalista sobre a referida decisão: "a decisão do Senado Federal foi uma grande tragédia, porque com a continuação da pesca agente [sic] tinha a esperança que ia aumentar o nosso mercado de trabalho". ${ }^{32}$

O desapontamento do sindicalista Severino Freire das Neves com a decisão do Senado foi novamente demonstrado quando ele faz menção, na mesma matéria, ao apoio que os trabalhadores de Lucena recebiam da Copesbra, mesmo quando o período de "pesca" era encerrado no mês de dezembro e os trabalhadores temporários ficavam afastados dos trabalhos baleeiros por quase seis meses, desenvolvendo atividades de subsistência como agricultura e pesca artesanal:

Os pescadores consideravam o restante dos meses como se estivessem de férias. Quando terminava a pesca, os trabalhadores recebiam todos os direitos trabalhistas da Copesbra (...) com o dinheiro o pescador comprava uma rede e uma canoa para pescar até chegar o início da pesca da baleia. ${ }^{33}$

Em vários momentos da trajetória de luta contra a caça à baleia até a decretação do fim da atividade no Brasil, os depoimentos dos líderes baleeiros e dos próprios trabalhadores empregados na Copesbra, publicados em jornais e revistas da época, são sempre em defesa dos

\footnotetext{
${ }^{31}$ Segundo João Paulo Capobianco (Dicionário ilustrado de ecologia. São Paulo: Revista Terra; Azul, 1998), o efeito estufa é gerado por uma camada de gases que envolve a Terra, impedindo que o calor que reflete na superfície do planeta volte para o espaço, gerando aumento de temperatura no planeta.

32 BALEIA: trabalhadores reagem contra a proibição. Correio da Paraíba, João Pessoa, 18 dez. 1987. Geral, p. 7.

${ }^{33}$ Ibid.
} 
interesses da referida atividade econômica para que se lograsse garantida a manutenção do emprego e da remuneração que eram mantidas pela empregadora japonesa.

A mensagem contida nas palavras do presidente do Sindicato da Pesca e da Extração do Óleo da Baleia de Lucena fortalece uma lógica subjacente em praticamente todos os discursos dos atores sociais estudados identificados com a defesa da permanência da atividade baleeira no estado da Paraíba, qual seja, a manutenção do emprego dos trabalhadores ligados à caça da baleia deve sobrepor-se aos interesses daqueles que lutam pelo equilíbrio ecológico e pela preservação das espécies ameaçadas de extinção. Um discurso que se apresentava voltado à causa social, mas que também se mostrava, conforme sugere Morin, ${ }^{34}$ revelador de concepções economicistas e antropocêntricas, características de uma formação humana fragmentada e reducionista.

Na mesma reportagem de dezembro de 1987, o jornal abriu espaço para que Creginaldo da Silva, então presidente da Apan, ao ser indagado sobre a votação da referida lei, definisse sua aprovação como "uma conquista do povo brasileiro". Para o presidente da Apan, a proibição da caça às baleias deveria servir de exemplo para outros recursos naturais, que estavam sendo explorados "aleatoriamente, quando não se tinham dados técnicos e científicos que garantissem a sua exploração racional com vistas à preservação dos recursos naturais para gerações futuras".

As palavras do presidente da Apan chamam atenção pela preocupação evidenciada com a exploração racional dos recursos naturais, com vistas à garantia de sua continuidade também pelas gerações futuras. $\mathrm{O}$ discurso do desenvolvimento sustentável, implícito nas declaraçôes do dirigente da Apan, se tornaria gradativamente hegemônico nas décadas de 1980 e 1990, principalmente com a publicação do Relatório Brundtland, documento de 1987, e com a Conferência Mundial sobre o Meio Ambiente e o Desenvolvimento (Rio-92), que passaram a assumir, sob coordenação da Organização das Naçôes Unidas (ONU), um papel de destaque na reformulação do discurso e das práticas ambientalistas em praticamente todo o mundo ocidental a partir das últimas décadas do século XX.

O Relatório Brundtland, que recebeu também o nome Nosso futuro comum, reformulou o conceito de desenvolvimento, definindo-o como aquele que compatibiliza crescimento econômico com respeito aos limites ecológicos. Um desenvolvimento que deveria satisfazer as necessidades da geração presente sem comprometer a capacidade de as gerações futuras satisfazerem as suas próprias necessidades.

O documento elaborado sob a presidência da norueguesa Gro Harlen Brundtland (originou-se daí o nome do relatório) enfatiza que o desenvolvimento adjetivado de sustentável é mais do que crescimento. $\mathrm{O}$ novo momento exige uma mudança no teor de crescimento a fim de torná-lo menos intensivo em matérias-primas e energia, procurando ser mais equitativo em seu impacto. $\mathrm{O}$ documento ainda pregava que as mudanças precisavam ocorrer em todos

\footnotetext{
${ }^{34}$ MORIN, Edgar; KERN, Anne Brigitte. Terra pátria. 6. ed. Rio de Janeiro: Salinas, 2011.
} 
os países, como parte de um pacote de medidas para manter a reserva de capital ecológico, melhorar a distribuição de renda e reduzir o grau de vulnerabilidade às crises econômicas. Os ambientalistas paraibanos absorveriam, sem questionamentos, o discurso elaborado pelos países centrais do capitalismo que objetivava compatibilizar crescimento econômico com equilíbrio ecológico.

O conceito de desenvolvimento sustentável que o Relatório Brundtland disseminou no fim da década de 1980, e que tem influência no discurso de Creginaldo da Silva, um dos mais destacados representantes do ambientalismo paraibano da época, deve ser considerado relevante para melhor se compreenderem avanços e limites do movimento ambientalista no Brasil e na Paraíba. No caso desse estado da federação, o movimento ecológico surgiu e se fortaleceu paralelamente à luta contra a atividade baleeira praticada em Lucena. ${ }^{35}$

As análises e as discussões mais profícuas sobre o conceito e sobre a definição de desenvolvimento adjetivado de sustentável, conforme difundido pelo Relatório Brundtland, viriam nas décadas seguintes quando Ignacy Sachs ${ }^{36}$ e Enrique Leff, ${ }^{37}$ principalmente, formularam várias críticas à falta de consenso sobre o seu significado, à heterogeneidade dos interesses no uso do termo e à sua apropriação para o atendimento de interesses sociais e econômicos diversos.

O professor Enrique Leff, especialmente, ao criticar e aprofundar o conceito de desenvolvimento sustentável, vai fazer referência a ele como um projeto social e político que deveria apontar para o ordenamento ecológico e a descentralização territorial da produção, assim como para a diversificação dos tipos de desenvolvimento e dos modos de vida das várias populaçóes que habitam o planeta. $\mathrm{O}$ autor de Epistemologia ambiental e saber ambiental também contribuiu com a discussão sobre a natureza ideológica das questóes ambientais. Segundo ele, a problemática ambiental não é ideologicamente neutra. Ela atende a determinados interesses políticos e econômicos de grupos que utilizam o discurso racionalista para manter seu poder dentro da sociedade. A relação estreita entre saber e poder, outrora tão bem analisada por Foucault, ${ }^{38}$ é percebida como muito importante, senão fundamental, para se compreenderem as relaçóes sociais e econômicas em um mundo marcado pelo poder do capital e pela globalização crescente dos mercados.

$\mathrm{Na}$ esteira da discussão sobre desenvolvimento sustentável, portanto, algumas matérias jornalísticas da época oferecem indícios de como o movimento ambientalista na Paraíba nasceu, cresce e amadureceu em torno da luta contra a atividade de exploração animal, es-

\footnotetext{
${ }^{35}$ A Associação Paraibana dos Amigos da Natureza (Apan), fundada em 1978, é considerada a mais antiga entidade de defesa ambiental do Nordeste brasileiro em atividade. Seus membros possuem uma história destacada de atuaçóes nas mais diferentes causas relacionadas à defesa do meio ambiente e dos ecossistemas da Paraíba. Com destaque na luta pela instituição da Lei Federal no 7.643/1987, que determinou o fim da caça à baleia em águas jurisdicionais brasileiras.

${ }^{36}$ SACHS, Igany. A terceira margem. São Paulo: Companhia das Letras, 2009.

${ }^{37}$ LEFF, Enrique. Epistemologia ambiental e saber ambiental. 4. ed. São Paulo: Cortez, 2006.

${ }^{38}$ FOCAULT, Michel. Microfisica do poder. 15. ed. Graal: Rio de Janeiro, 2000.
} 
tando a caça da baleia no centro do conflito. ${ }^{39}$ Alguns textos de autoria dos ambientalistas paraibanos, como o do próprio Creginaldo, e de empresários e políticos da regiáo sugerem em seu teor a influência de ideias e concepçôes presentes no Relatório Brundtland ${ }^{40}$ lançado em 1987. Termos como "exploraçáo racional dos recursos naturais" e "desenvolvimento sustentável" já estavam em construção e eram divulgados pelos meios de comunicação de massa no final dos anos 1980. Alguns desses discursos ${ }^{41}$ materializados pelos jornais da época, podem ser utilizados como objeto de análises e reflexôes, corroborando essa constatação.

\section{Políticos paraibanos e empresários de plantão: lobby pela manutenção da caça à baleia}

Ao longo da pesquisa realizada nos jornais de João Pessoa da época, foi se evidenciando que havia certa sintonia entre as ideias e os discursos do empresariado ligado ao ramo pesqueiro e a classe política do estado da Paraíba. Alguns fragmentos de falas recuperados dos jornais da década de 1980 confirmam a confluência de ideias e concepçôes defendidas por esses setores da sociedade paraibana quando se tratava da caça à baleia.

Vários documentos da época, principalmente os jornais da capital paraibana, puderam testemunhar que a classe política paraibana e os empresários ligados ao setor pesqueiro também se envolveram nos debates sobre a questão da caça à baleia. A preocupação em torno da manutenção ou fim da atividade baleeira no país, cujos reflexos maiores ocorreriam na Paraíba, levou alguns parlamentares do estado com mandatos eletivos durante a década de 1980 a assumir publicamente, em vários momentos dos debates, posição política favorável à manutenção da caça à baleia praticada no litoral norte da Paraíba. Entre os políticos mais atuantes em defesa dos interesses da economia baleeira podem ser identificados os governadores Tarcísio de Miranda Burity (1979-1982), Clóvis Bezerra Cavalcanti (1982-1983), Wilson Leite Braga (1983-1986) e Milton Bezerra Cabral (1986-1987). O deputado federal Raimundo Asfora e os deputados estaduais Edvaldo Mota, Jório de Lira Machado e Ramalho Leite também são identificados com os interesses da permanência do empreendimento baleeiro em Lucena.

\footnotetext{
${ }^{39}$ Segundo depoimento de Paula Frassinete Lins Duarte, de 14 de setembro de 2011, quando do surgimento da Apan em 1978, duas grandes lutas constavam da agenda da entidade: o fim da caça à baleia em Lucena e a preservação do Cabo Branco em João Pessoa.

${ }^{40}$ COMISSÃO MUNDIAL SOBRE MEIO AMBIENTE E DESENVOLVIMENTO. Nosso futuro comum. 2. ed. Rio de Janeiro: Fundação Getulio Vargas, 1991.

${ }^{41}$ De acordo com matéria intitulada: "Ecologistas consideram uma conquista da sociedade", publicada pelo Correio da Paraíba (João Pessoa, 18 dez. 1987. Geral, p. 2), Creginaldo da Silva, na época presidente da Apan, voltando a se posicionar sobre o fim da caça à baleia, argumentou que a referida proibição deveria ser extensiva a outros recursos naturais que estavam sendo explorados no Brasil sem controle por parte dos órgãos governamentais.
} 
No ano de 1982, durante o mandato presidencial do general Joáo Batista de Oliveira Figueiredo, quando se iniciavam as discussóes sobre um fim iminente da caça à baleia no Brasil, um jornal de João Pessoa expressava a preocupação de Clóvis Bezerra Cavalcanti, então governador ${ }^{42}$ da Paraíba, com a possibilidade de a caça à baleia não ser autorizada naquela temporada. O jornal pessoense manifestou a preocupação do chefe do Executivo paraibano da seguinte maneira:

O governador Clóvis Bezerra enviou telex ao presidente João Figueiredo externando sua preocupação com o fato da Sudepe ainda não ter recebido a garantia de que a pesca da baleia não será interrompida este ano, como ocorreu no ano passado. Na mensagem enviada ontem ao presidente da República, o governador paraibano explicou que na temporada de 1981 "o setor foi surpreendido com uma redução de dez por cento do nível de captura". ${ }^{43}$

Numa primeira análise, é importante considerar a data em que a matéria é publicada: $1^{-}$de junho de 1982. Período do ano em que as baleias minke começam a migrar para as águas do litoral brasileiro para cumprir o ritual de acasalamento e procriação. Período de "safra", como era comumente chamado pelos baleeiros o período compreendido entre junho e dezembro de cada ano.

Além de demonstrar preocupação por não ter recebido a garantia de que a atividade baleeira seria mantida naquele ano, é interessante observar que, ao concluir suas consideraçôes sobre a necessidade da liberação da atividade baleeira para o ano em curso, sem prejuízo na cota estabelecida, o governador acrescente ao seu texto fragmentos do discurso que fortaleciam ideias e concepções de segmentos sociais favoráveis à manutenção da atividade baleeira na Paraíba. Segundo o jornal, na mensagem, Clóvis Bezerra pede que o presidente Figueiredo dê instrução aos setores competentes "no sentido de manter intacta a dotação de captura do Brasil, pois qualquer decisão ao contrário comprometerá o nível já projetado de oferta de proteínas, a taxa de emprego e a contribuiçáo tributária da atividade ao Estado e ao município". ${ }^{44}$

O jornal Correio da Paraíba, em sua edição do dia 20 de agosto de 1985, trouxe matéria reproduzindo o discurso do deputado estadual Edivaldo Mota, em que defendeu publicamente a manutenção da atividade baleeira. Como consta no jornal, Edvaldo Mota ocupou a tribuna da Assembleia Legislativa para dizer que a Paraíba iria sair perdendo com o fim da atividade baleeira e apelou ao governo federal para rever essa posiçáo, acrescentando que os

\footnotetext{
${ }^{42}$ Clóvis Bezerra Cavalcante foi eleito vice-governador da Paraíba em 1979 ao lado de Tarcísio de Miranda Burity. Em 1982, assumiu definitivamente o governo da Paraíba, quando o titular se afastou do cargo para se candidatar a deputado federal.

${ }^{43}$ CLÓVIS pede garantia para caça à baleia. A União, Joáo Pessoa, 1o jun. 1982. Geral, p. 5.

${ }^{44}$ Ibid., p. 5.
} 
outros países que praticavam essa modalidade de pesca não suspenderam suas atividades. ${ }^{45}$ Em tom dramático, o deputado do PMDB acrescentou no final de seu discurso que "a Paraíba é quem vai sair perdendo com a paralisação da pesca, porque perderá ICM, deixará centenas de famílias sem emprego e aumentará a miséria no município de Costinha, motivos pelos quais a atividade não deveria ser proibida" ${ }^{46}$

É interessante perceber no discurso do parlamentar, claramente em defesa da manutenção da atividade baleeira, que ele acaba confirmando um fato que o ambientalista Moacyr Madruga já havia denunciado sobre as condiçóes de "vida miserável” em que se encontrava a comunidade de Costinha na época em que vigorava a atividade baleeira, mesmo com os benefícios que a Copesbra alegava trazer para a região. Nas palavras do deputado Edvaldo Mota, a desativação do empreendimento baleeiro "aumentará a miséria no município". A frase remete a uma reflexão: se há uma preocupação com a possibilidade de aumentar a miséria, é porque se entende que ela já existe...

Em nível nacional, o jornal O Estado de S. Paulo, datado de 7 de julho de 1985, divulgou uma matéria onde destaca a tentativa do então governador da Paraíba, Wilson Braga, de influenciar na posição que o Brasil deveria adotar na International Whaling Commission (IWC), encontro de representantes baleeiros que ocorria naquele ano em Londres, onde se discutiriam as questóes relacionadas à atividade:

Ogovernador da Paraíba, Wilson Braga, quer que o Brasil defenda junto à Comissão Internacional da Baleia, reunida durante todo o mês de julho, em Londres, posição não conservacionista no que diz respeito à pesca da baleia. (...) Ofício neste sentido foi encaminhado pelo governador ao ministro da Marinha, almirante Henrique Sabóia, que também é presidente da Comissão Interministerial de Recursos do Mar (Cirm). Isso porque, é na cidade paraibana de Lucena que se encontra o único foco brasileiro de pesca de baleia, representado pela Companhia de Pesca Norte do Brasil - Copesbras - de capital japonês. Ela emprega cerca de 300 pessoas da cidade e a Sudepe, embora ache que a captura de um determinado número de baleias para pesquisa deva ser mantido, começa a acionar um antigo programa de atividades alternativas para a população de Lucena. Através de convênio com a Sudene, o superintendente da Sudepe, Petronilo Santa Cruz, estuda a possibilidade de aplicar ali o programa de pesca artesanal (sobretudo atum e algas), comprovadamente rentável para a população. ${ }^{47}$

Conforme se pode inferir da matéria, o governador, como representante dos interesses da população paraibana, demonstrava preocupação com o destino dos trabalhadores baleeiros que viviam da atividade no município de Lucena. Chamando atenção para o problema do

\footnotetext{
${ }^{45} \mathrm{O}$ parlamentar paraibano se referia à então União Soviética, Japão, Noruega e Islândia, países que mantiveram a caça comercial de baleias mesmo depois da moratória de 1985 determinada no âmbito da IWC.

${ }^{46}$ DEPUTADO contra suspensão da pesca à baleia. Correio da Paraíba, 20 ago. 1985. p. 3.

${ }^{47} \mathrm{~PB}$ quer continuar caçando baleias. O Estado de S. Paulo, 7 jul. 1985. p. 2.
} 
desemprego que o fim iminente da atividade provocaria no município, Wilson Braga assumiu posição não conservacionista, conforme palavras expressas no próprio jornal paulista.

Observa-se que, diferentemente de outras matérias que evidenciaram a posição de autoridades paraibanas, o jornal paulista trouxe um elemento novo que começava a ser incorporado nos discursos dos defensores da "pesca da baleia" com o objetivo de manter, mesmo em condiçóes adversas, a atividade econômica em funcionamento no município de Lucena: manter a captura de um determinado número de animais para que pesquisas cientificas pudessem ser realizadas com os animais capturados em Costinha. Os japoneses se utilizaram dessa estratégia mesmo depois de decretada a moratória de 1985, mantendo, ainda que contrariando a posição de vários países signatários da IWC, a caça comercial clandestina com animais provenientes das águas da região Antártica, alegando "pesca para fins científicos”.

Quanto aos representantes da classe empresarial paraibana, Guilherme Campelo Rabay foi destacadamente o maior defensor da continuidade da atividade baleeira no país. Considerado o mais influente empresário ligado à Copesbra, Rabay escreveu dezenas de artigos para os jornais paraibanos procurando mostrar a viabilidade social e econômica da atividade baleeira instalada há décadas em Lucena. Era também o representante mais proeminente da Companhia de Pesca Norte do Brasil em reunióes com autoridades brasileiras e estrangeiras, quando se tratava de defender os interesses da indústria nipo-brasileira instalada no litoral norte da Paraíba.

Era o escolhido pela empresa nipo-brasileira, nos últimos anos da caça à baleia, para se pronunciar na imprensa paraibana sobre as questóes de interesse da atividade baleeira. Guilherme Campelo Rabay é, sem dúvida, o personagem que mais vezes utilizou a imprensa paraibana para defender os interesses da empresa japonesa. Sua presença nos jornais analisados é marcante, principalmente no período mais agudo do embate sobre o fim da atividade baleeira no país, entre 1980 e 1987. Respondia aos seus opositores da caça à baleia sempre baseado em resultados econômicos que eram gerados pela empresa baleeira. Amparado por dados estatísticos elaborados por especialistas da Copesbra, era contundente em seus argumentos e, às vezes, destemperado.

Uma entrevista publicada pelo jornal $A$ União, datado de 5 de julho de 1981, traduziu a indignação de Guilherme Campelo Rabay quando perguntado sobre uma campanha contra a pesca da baleia, organizada no estado vizinho, Pernambuco, que contou, segundo o jornal pessoense, com o apoio de autoridades e pessoas ligadas à defesa do meio ambiente. Para Guilherme Rabay, “é um direito que eles têm (de protestar). Mas acredito que se a indústria fosse localizada lá eles não fariam essas manifestações”.

O empresário deu continuidade ao seu depoimento ao jornal enfatizando que a "pesca da baleia” era muito importante para a região, uma vez que a mesma se constituía no único empreendimento gerador de emprego e renda existente no município de Lucena: "Só para 
dar um exemplo da importância desse empreendimento, 80 por cento do orçamento daquele município dependem da Copesbra”. ${ }^{48}$

Conforme se pode deduzir do discurso de Rabay, a linha de argumentos em defesa da manutenção da atividade baleeira, utilizada nas narrativas expostas nos jornais, evidencia certa lógica que é seguida por representantes de vários setores da sociedade paraibana, citados ao longo do trabalho. Uma linha de raciocínio que exalta a importância dos dados econômicos como meio de demonstrar a viabilidade social e econômica do empreendimento, como forma de sensibilizar a opiniáo pública e as autoridades do país diante do problema do desemprego iminente que o fim do extrativismo animal provocaria no seio da população lucenense. Essa pode ser uma das leituras possíveis dos depoimentos e discursos analisados, que pretenderam defender a permanência da atividade baleeira em Lucena no decorrer dos anos 1980.

\section{Consideraçóes finais: mudanças de percepção e de comportamento humano em relação às baleias}

Não parece exagero afirmar que a maioria dos discursos analisados, proferidos por ambientalistas e simpatizantes de ideias voltadas à defesa das baleias, vencedores do embate, evocou a questão da perpetuação da espécie, do direito de os animais se reproduzirem e do respeito à vida como principal linha argumentativa para alcançar seus objetivos. A esse respeito, os argumentos dos ambientalistas quanto ao direito à reprodução e à própria vida das baleias sugerem a existência de consideráveis mudanças no comportamento de uma parcela importante da humanidade, particularmente na sensibilidade refletida no trato com outros seres vivos.

No caso estudado, particularmente com as baleias, sabe-se que hoje esses animais recebem um tratamento diferente daquele feito no passado. Essa conclusão, embora dedutiva, pode ser feita considerando que a luta pelo fim da caça à baleia tornou-se mundial, praticamente uma exigência das mais diferentes sociedades e culturas. Em diversos países do mundo, como Espanha, Estados Unidos, Alemanha, França, Brasil, ocorreram mobilização e pressão para que as autoridades tomassem providências acerca das espécies baleeiras ameaçadas de extinção em razão do comércio de derivados que provocou um efeito dominó entre as espécies caçadas em todo o planeta. ${ }^{49}$

O processo de mudanças em relação à percepção da natureza, o emergir de "novas sensibilidades" humanas para com os demais seres vivos, embora lentos e pouco estudados,

\footnotetext{
${ }^{48}$ COPESBRA já capturou seis baleias em apenas três dias. A União, 5 jul. 1981. p. 2.

${ }^{49}$ DOLIN, E. J. Leviathan: the history of whaling in American. Nova York: W. W. Norton \& Company, 2007.
} 


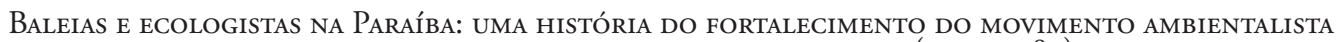
E O DEBATE SOBRE A CRISE DA ECONOMIA BALEEIRA (I970-I980)

Francisco Henrique Duarte Filho e José Otávio Aguiar

parecem ter sido iniciados nos últimos cinco séculos em todo o mundo ocidental. Essas mudanças, embora imperceptíveis para a maioria das pessoas, são representativas, uma vez que expressam transformaçóes mentais e culturais importantes, principalmente nas relações entre sociedade e natureza.

Não parece absurdo considerar, por conseguinte, que essa redefinição do relacionamento dos humanos com a natureza, a que se refere Keith Thomas ${ }^{50}$ no caso inglês, tenha se difundido com o passar do tempo por entre países mais distantes da Europa, ou até mesmo que tenha assumido características próprias em cada sociedade, de acordo com as mudanças sociais, políticas e culturais ocorridas ao longo das últimas décadas em cada país.

O processo de colonização e integração cultural do continente americano, levado a cabo pelos países europeus em fins do século XV e início do XVI, permite sugerir a tese de que traços dessas "novas sensibilidades" passaram a ser incorporados paulatinamente à cultura dos povos colonizados. Todavia, é possível que nos países americanos os registros históricos sobre as mudanças nas relaçóes entre humanos e a natureza, às quais se refere Thomas, não permitam estudo sobre o tema no nível de aprofundamento tal qual utilizado pelo referido autor na pesquisa sobre o caso inglês. Mas isso não significa que não se podem identificar, principalmente no último século, mudanças de atitudes e comportamentos da maioria das pessoas em relação à natureza no Velho Mundo (como no caso inglês) e em algumas ex-colônias americanas, como no Brasil. Basta analisar, como exemplo para reflexóes, as mudanças de atitudes e de comportamento da maioria do povo brasileiro em relação às baleias. De mamíferos que chegaram a meados do século XX em processo de extinção, passaram a animais preservados e protegidos por lei no final do mesmo século.

A caça predatória aos cetáceos no Brasil, iniciada ainda pelos colonizadores ibéricos no início do século XVII, perdurou por quase quatro séculos, mas atualmente o comércio e a indústria baleeira fazem parte do passado do país. A legislação ambiental brasileira protege esses animais não apenas contra a exploração comercial e industrial, mas contra qualquer tipo de molestamento. Talvez com exceção de trabalhadores baleeiros remanescentes de Lucena, em um universo micro no qual algumas pessoas ainda reivindicam um retorno à antiga atividade que era promovida pela Copesbra, parece inconcebível atualmente defender esse tipo de relação predatória com essas espécies.

A lei federal sancionada em 1987 que proibiu a caça e "qualquer forma de molestamento aos cetáceos" pode ser considerada, de fato, uma conquista, resultado de mudanças na percepção e nas ações dos brasileiros para com a natureza em geral e para com esses animais em particular. No Brasil de hoje, as baleias são espécies protegidas e preservadas por leis e decretos. Recentemente, o então presidente Luiz Inácio Lula da Silva, por meio do Decreto $\mathrm{n}$ - 6.698/2008, transformou as águas jurisdicionais brasileiras em Santuário de Baleias e

\footnotetext{
50 THOMAS, Keith. O homem e o mundo natural: mudanças de atitude em relação às plantas e aos animais (1500-1800). Tradução de João Roberto Martins Filho. São Paulo: Companhia das Letras, 2001.
} 
Golfinhos. Mais um passo para o reconhecimento da importância que esses animais passaram a adquirir para a história da relação entre sociedade e natureza no Brasil.

Quanto ao papel social e econômico da empresa baleeira, mesmo questionada por alguns setores da sociedade como um empreendimento que explorava a máo de obra e os recursos naturais em águas paraibanas, ainda hoje é reconhecida pelos moradores como "uma empresa boa", que "pagava em dia", que "ajudou a criar nossos filhos". Se considerarmos que vivemos em uma sociedade onde o trabalho é sinônimo de dignidade, de cidadania, embora o trabalhador seja também explorado para o enriquecimento dos donos do capital, é possível sugerir, com base nas narrativas dos ex-baleeiros e nas reportagens analisadas, que a Copesbra ajudava a aliviar algumas tensóes sociais e a melhorar relativamente as condiçóes de vida de uma população secularmente marginalizada pelo poder público. Todavia, a um custo social e ambiental muito alto. Basta recordar que, para a garantia da manutenção do nível de emprego oferecido pela Copesbra, centenas de baleias precisavam ser abatidas a cada temporada e dezenas de trabalhadores, por sua vez, eram explorados pela mesma empresa, que obtinha lucros consideráveis mediante a comercialização de derivados baleeiros.

É importante considerar que, para uma gente necessitada, excluída das políticas públicas e oriunda muitas vezes de condiçóes de trabalho escravizante, como da cana-de-açúcar e do cultivo de coco, produtos também explorados na região, a Copesbra ofereceu trabalho, carteira assinada e uma remuneração semanal acima da média da região. Renda que poderia ainda ser acrescida de novos valores com as horas adicionais trabalhadas ao longo da jornada. Não é de se estranhar que os trabalhadores baleeiros, em sua maioria, quando na época do conflito para pôr fim à atividade, se mobilizaram para defender a permanência da "pesca da baleia”. O que, na realidade, pode indicar que os mesmos defendiam a manutenção do emprego e da renda que a atividade proporcionava, e não necessariamente a manutenção da morte desses animais.

As possibilidades viáveis para se melhorar de vida em uma dada região aonde se instalam novos empreendimentos econômicos, oferecendo emprego e renda para a população carente, devem ser consideradas como fatores relevantes, quando não decisivos, para a formação da realidade social e econômica desse lugar. O exemplo da Copesbra, que se instalou e funcionou em Lucena por mais de setenta anos, utilizando-se da mão de obra local e dos recursos naturais da região, além de um mercado consumidor para seus produtos sempre crescente, pode ser oferecido para novas reflexões acerca desse fenômeno que é antigo, mas relativamente comum em cidades do interior do Brasil.

A partir da investigação, ainda se pode concluir que, diferentemente de como foi discursado na década de 1980 por alguns segmentos da sociedade paraibana, principalmente a classe política e empresarial do estado que eram favoráveis à manutenção da caça à baleia, essa atividade não representava para a comunidade de Lucena o único meio de sobrevivência material, e nem seu fim culminou no colapso da economia local, visto que a pesquisa 
empírica oferece fortes indícios que ajudam na constatação de que, mesmo sem a presença da empresa japonesa, diversas estratégias de sobrevivência foram sendo desenvolvidas em Lucena (ou em cidades circunvizinhas), como alternativa de trabalho e renda para as famílias dos ex-trabalhadores que resolveram permanecer na região. Entre essas alternativas, encontrava-se o retorno à pesca artesanal, atividade secularmente praticada na região, mas que havia sido quase abandonada pelas comunidades tradicionais quando da implementação do empreendimento baleeiro. 